\title{
A RANDOMISED, DOUBLE-BLIND, PROSPECTIVE STUDY OF CAUDAL ROPIVACAINE VERSUS ROPIVACAINE WITH FENTANYL VERSUS ROPIVACAINE WITH NEOSTIGMINE FOR COMBINED EPIDURAL AND GENERAL ANAESTHESIA IN CHILDREN
}

\author{
Manem Prasad Rao', Soumya Panickessery Babu², Patta Saroj ${ }^{3}$
}

${ }^{1}$ Associate Professor, Department of Anaesthesiology, Rajiv Gandhi Institute of Medical Sciences, Srikakulam, Andhra Pradesh. ${ }^{2}$ Senior Resident, Department of Anaesthesiology, Rajiv Gandhi Institute of Medical Sciences, Srikakulam, Andhra Pradesh. ${ }^{3}$ Professor, Department of Anaesthesiology, Rajiv Gandhi Institute of Medical Sciences, Srikakulam, Andhra Pradesh.

\section{ABSTRACT}

\section{BACKGROUND}

There are no studies comparing the outcomes of using Fentanyl or Neostigmine as adjuvants to Ropivacaine in terms of postoperative analgesia for paediatric caudal block. The aim of our study is to compare the outcomes of using Ropivacaine $0.2 \%$ vs Ropivacaine $0.2 \%$ with Neostigmine $2 \mathrm{mcg} / \mathrm{kg}$ vs Ropivacaine with Fentanyl $1 \mathrm{mcg} / \mathrm{kg}$ as a single shot caudal block on postoperative analgesic effect in children aged 3 - 8 yrs. undergoing subumbilical surgeries.

\section{MATERIALS AND METHODS}

This is a double-blind, randomised, controlled, prospective study. Our study included 60 paediatric patients undergoing elective lower abdominal surgeries at Rajiv Gandhi Institute of Medical Sciences, Srikakulam, Andhra Pradesh.

\section{RESULTS}

The patient groups were comparable with respect to age and weight. The mean pain scores at 24 hrs. in $R, R F$ and $R N$ groups are $3.05 \pm 0.6,2 \pm 0.5,2.65 \pm 0.67$ respectively with a p-value of 0.008 , which is statistically significant. The duration of analgesia in $R$, $\mathrm{RF}$ and RN groups are 383, 353 and 680.5 mins. respectively with a p-value of $<0.05$, which is statistically significant.

\section{CONCLUSION}

We conclude in the present study that the addition of neostigmine to caudal Ropivacaine resulted in prolongation of duration of analgesia, while a Ropivacaine and Fentanyl mixture did not cause any statistically significant increase in the duration of analgesia.

\section{KEYWORDS}

Ropivacaine, Fentanyl, Neostigmine, Caudal Analgesia.

HOW TO CITE THIS ARTICLE: Rao MP, Babu SP, Saroj P. A randomised, double-blind, prospective study of caudal ropivacaine versus ropivacaine with fentanyl versus ropivacaine with neostigmine for combined epidural and general anaesthesia in children. J Evolution Med. Dent. Sci. 2017;6(44):3459-3468, DOI: 10.14260/Jemds/2017/748

\section{BACKGROUND}

Pain is "an unpleasant sensory and emotional experience associated with actual or potential tissue damage or described in terms of such damage" as defined by the International Association for the Study of Pain.[1] Pain is always subjective.

In children even the definition of pain has been debated. ${ }^{2]}$ The structural components necessary to perceive pain are already present at about 25 weeks gestation, whereas the endogenous descending inhibitory pathways are not fully developed until mid-infancy. ${ }^{[3,4]}$

It has been recognised for some time that the management of acute pain, especially post-operative pain, has been consistently inadequate. If anything, the situation in children has been even worse, who have long been undermedicated for acute pain. [5]

The various drugs used for the treatment of acute postoperative pain are local anaesthetics (local/regional

Financial or Other, Competing Interest: None.

Submission 21-04-2017, Peer Review 19-05-2017,

Acceptance 25-05-2017, Published 01-06-2017.

Corresponding Author:

Dr. Soumya Panickessery Babu

D/No. 39-6-72, Muralinagar,

Visakhapatnam-530007.

E-mail: pbsoums.k@gmail.com

DOI: $10.14260 /$ jemds $/ 2017 / 748$

\section{(c) $(1) \Theta$}

analgesia), opioids, Non-Steroidal Anti-Inflammatory Drugs (NSAIDs) and acetaminophen. The different available routes of administration are oral, intravenous, subcutaneous, rectal or transdermal.

The use of regional anaesthetic techniques in infants and children has become increasingly accepted as standard of care, as it produces excellent post-operative analgesia and attenuation of the stress response in infants and children.[6,7, 8,9,10,11]

Caudal block since its first description in 1933 for paediatric urological interventions has evolved to become the most popular regional anaesthetic technique for use in children.[12] It provides excellent analgesia during surgery as well as during post-operative period in subumbilical surgeries in children.[13] The block is perhaps the most easily learned and mastered of all regional anaesthetic techniques.[14]

Although, it is a versatile block, one of the major limitations of a single-injection technique is the relatively short duration of post-operative analgesia ( $4-6 \mathrm{hrs}$.) that accompanies the use of even long-acting local anaesthetics. Probably, the most frequently used method to further prolong post-operative analgesia following caudal block is to add different adjuvant drugs to the local anaesthetic solution. Epinephrine was the earliest adjunct drug used.

Krane and Colleagues in 1988 published dose-response data for morphine as an adjuvant to caudal anaesthesia in children.[15] Soon after this, the successful use of both racemic 
ketamine and clonidine was described.[16,17,18] Abdulatif and Colleagues,[19] reported a seemingly good effect of adjunct neostigmine.

A large safety study has established safe-dosing guidelines for racemic bupivacaine in children.[20,21] Racemic bupivacaine is gradually being replaced by ropivacaine or levobupivacaine. This change is driven by the reduced potential for systemic toxicity and the lower risk of unwanted motor blockade. There are now sufficient paediatric data to recommend either of the new agents. $[22,23,24,25,26,27]$

For single injection of caudal blockade, ropivacaine provides similar post-operative analgesia compared to racemic bupivacaine with lower chances of post-operative motor blockade.[28,29] Thus, because of all the advantages of Ropivacaine, we have chosen it in the present study.

There are many individual studies on the usage of caudal fentanyl and caudal neostigmine. Regarding the addition of fentanyl to caudal local anaesthetic solutions, there are two views. Some studies concluded that the addition of fentanyl caused prolonged analgesia, while others have found no added benefit. Neostigmine is a relatively new drug being tried as an adjunct for caudal block.

There are no studies comparing the efficacy of these two drugs in terms of post-operative analgesia for paediatric caudal block. So this study has been undertaken to compare the post-operative analgesic efficacy and safety of addition of fentanyl and neostigmine to $0.2 \%$ ropivacaine for caudal block in paediatric surgeries.

\section{MATERIALS AND METHODS}

Sixty paediatric patients undergoing various elective lower abdominal surgeries like circumcision, orchidopexy, herniotomies, etc. and belonging to ASA Grade I and II were selected for this study for convenience. This study was conducted in Rajiv Gandhi Institute of Medical Sciences, Srikakulam, Andhra Pradesh from February 2016 to March 2017.

\section{Inclusion Criteria}

- $\quad$ Age group: 3 - 8 yrs.

- $\quad$ ASA Grade 1 and 2.

- Parental consent.

- $\quad$ Elective lower abdominal surgeries.

\section{Exclusion Criteria}

- Patients with known allergy to the study drugs.

- Infection at the site of caudal block.

- Any coagulopathies.

- Congenital abnormalities of lower spine and meninges.

- History of developmental delay and neurological diseases.

- Parental refusal.

After obtaining clearance from the Ethics and Standard Committee of the hospital, the study was started. Informed consent was obtained from the parent before including the children in the study.

\section{Groups}

The present study was a double-blind, randomised, prospective study. The patients were divided into 3 groups of 20 each, randomly by chits on lottery basis. 60 chits were made with 20 each having $\mathrm{R}$ (Ropivacaine alone), $\mathrm{RF}$
(Ropivacaine + Fentanyl) and RN (Ropivacaine + Neostigmine) written on them. On arrival of the patient to the $\mathrm{OR}$, a chit was picked and without opening it was sent to the technician preparing the drug. The technician noted down the name of the patient and the drug given which was not revealed to the anaesthesiologist administering the caudal block and monitoring the patient. In this way, the doubleblindedness of the study was assured-

- Group $\mathrm{R}(\mathrm{n}=20)$ received $0.2 \%$ Ropivacaine $0.5 \mathrm{~mL} / \mathrm{kg}$ with normal saline $1 \mathrm{~mL}$.

- Group $\mathrm{RF}(\mathrm{n}=20)$ received $0.2 \%$ Ropivacaine $0.5 \mathrm{~mL} / \mathrm{kg}$ with Fentanyl $1 \mathrm{mcg} / \mathrm{kg}$ in normal saline $1 \mathrm{~mL}$.

- $\quad$ Group $\mathrm{RN}(\mathrm{n}=20)$ received $0.2 \%$ Ropivacaine $0.5 \mathrm{~mL} / \mathrm{kg}$ with Neostigmine $2 \mathrm{mcg} / \mathrm{kg}$ in normal saline $1 \mathrm{~mL}$.

\section{Equipment}

- 23-G hypodermic needle.

- $2 \mathrm{~mL}$ syringe, $5 \mathrm{~mL}$ syringe for whoosh test, $10 \mathrm{~mL}$ syringe, Insulin syringe.

- Sterile swabs, bowls, sponge holding forceps, sterile hole towel, Povidone iodine and spirit.

\section{Drugs}

- $\quad$ Ropivacaine $0.2 \%$ ampules.

- Fentanyl $2 \mathrm{~mL}$ ampules, $50 \mathrm{mcg} / \mathrm{mL}$.

- $\quad$ Neostigmine $5 \mathrm{~mL}$ ampules, $0.5 \mathrm{mg} / \mathrm{mL}$.

- Boyle's apparatus, vapouriser, Jackson Rees circuit, IV cannulas, crystalloids, sterile water.

\section{Emergency Equipment}

- Working laryngoscope with at least 2 appropriate sized blades.

- Endotracheal tubes of appropriate sizes.

- Appropriate airways and masks.

- Paediatric Ambu Bag.

- Suction apparatus.

- Emergency drugs like Inj. Atropine, Inj. Adrenaline.

- Defibrillator.

\section{Methods}

- All the patients were visited on the day before surgery. A detailed history, thorough physical examination including airway and spine examination was done. Informed consent was obtained from the parents.

- Necessary investigations were noted down.

- Baseline values of BP, HR and RR were noted.

- Solid food was restricted for 6 hours, milk for 4 - 5 hours and clear fluids for 2 - 3 hours prior to surgery.

- Patients were pre-medicated with oral Midazolam syrup $0.5 \mathrm{mg} / \mathrm{kg}, 1 / 2$ hour before induction.

- All standard monitors like pulse oximeter, temperature, NIBP and ECG were connected to patient in the OT.

- Patients were induced with sevoflurane in Oxygen. IV line was secured. Inj. Atropine $0.02 \mathrm{mg} / \mathrm{kg}$ was given. To facilitate endotracheal tube insertion, neuromuscular blocking agents were used. Bilateral air entry was confirmed and endotracheal tube position was secured. Patients were mechanically ventilated. Fluids were administered according to calculated doses.

- After securely placing the endotracheal tube, the patients were gently placed in lateral Sims' position. Position of endotracheal tube was reconfirmed. 
- Under strict aseptic precautions, sciatic hiatus was identified and a needle with its bevel facing anteriorly was inserted at an angle of 45 degrees to the skin till the sacrococcygeal membrane was pierced when a distinct pop was felt. The needle was then lowered to an angle of 20 degrees and advanced $2-3 \mathrm{~mm}$. Whoosh test was used for confirmation of needle placement. Aspiration was done to exclude dural/vessel puncture and then the study drug was injected.

- No systemic analgesia was given by any route preoperatively or intra-operatively. Volatile agents were used. The concentration of volatile agent was adjusted to achieve haemodynamic changes $<30 \%$ of baseline. The time of caudal block was noted.

\section{Parameters Studied \\ Haemodynamic Parameter}

Patients were monitored for HR and BP after administration of caudal block at $0,5,15,30,45,60,120$ and 180 minutes and the values were recorded.

\section{Duration of Analgesia}

Duration of analgesia was defined as the time interval $b / n$ the administration of caudal block and the $1^{\text {st }}$ requirement of supplementary analgesia for the patient.

\section{Post-Operative Analgesia}

Post-operative analgesia is assessed by Paediatric observational FLACC scale. The assessment was done for a period of 24 hours. If the pain score was $>4$ for 2 consecutive intervals of 10 minutes, then supplementary analgesia with rectal Paracetamol $15 \mathrm{mg} / \mathrm{kg}$ was given.

The FLACC Pain Scale: Asleep

\begin{tabular}{|c|c|c|c|}
\hline Categories & $\mathbf{0}$ & $\mathbf{1}$ & $\mathbf{2}$ \\
\hline Face & $\begin{array}{c}\text { Smile or no } \\
\text { particular } \\
\text { expression }\end{array}$ & $\begin{array}{c}\text { Occasional } \\
\text { grimace or } \\
\text { frown, } \\
\text { withdrawn or } \\
\text { disinterested }\end{array}$ & $\begin{array}{c}\text { Frequent to } \\
\text { constant frown. } \\
\text { Clenched teeth, } \\
\text { quivering chin }\end{array}$ \\
\hline Legs & $\begin{array}{c}\text { Normal/ } \\
\text { relaxed } \\
\text { position }\end{array}$ & $\begin{array}{c}\text { Uneasy, } \\
\text { restless, tense }\end{array}$ & $\begin{array}{c}\text { Kicking or } \\
\text { drawn up legs }\end{array}$ \\
\hline Crivity & $\begin{array}{c}\text { Lying quietly, } \\
\text { normal } \\
\text { position, } \\
\text { moves easily }\end{array}$ & $\begin{array}{c}\text { Squirming, } \\
\text { shifting back } \\
\text { and forth, tense }\end{array}$ & $\begin{array}{c}\text { Arched, rigid or } \\
\text { jerking }\end{array}$ \\
\hline $\begin{array}{c}\text { No cry } \\
\text { (awoke) }\end{array}$ & $\begin{array}{c}\text { Moans, } \\
\text { whimpers, } \\
\text { occasional } \\
\text { complaint }\end{array}$ & $\begin{array}{c}\text { Crying steadily, } \\
\text { screams or } \\
\text { sobs/repeated } \\
\text { complaints }\end{array}$ \\
\hline ability & $\begin{array}{c}\text { Content, } \\
\text { relaxed }\end{array}$ & $\begin{array}{c}\text { Reassured by } \\
\text { occasional } \\
\text { touching, } \\
\text { hugging or } \\
\text { talking to, } \\
\text { distractable }\end{array}$ & Difficult to \\
console
\end{tabular}

\section{FLACC Score}

0- No pain; 1 - 3 Mild pain; 4 - 7 Moderate; 8 - 10 Severe.

\section{Side Effects}

Patients were monitored for intra-operative and postoperative complications like nausea and vomiting.

\section{Bradycardia}

Any decrease in HR more than $30 \%$ of the baseline value. It was treated with Inj. Atropine $0.02 \mathrm{mg} / \mathrm{kg}$.

\section{Hypotension}

Any decrease in mean arterial pressure of $>30 \%$ of the baseline value. It was treated with rapid infusion of IV fluids and if that was unsuccessful, then Inj. Phenylephrine 2 - 10 $\mathrm{mcg} / \mathrm{kg}$.

\section{Sedation}

A four-point sedation score was used as follows.

\begin{tabular}{|c|c|}
\hline \multicolumn{2}{|c|}{ 4 Point Patient Sedation Score } \\
\hline 1 & Asleep; not aroused by verbal contact \\
\hline 2 & Asleep; aroused by verbal contact \\
\hline 3 & Drowsy/not sleeping \\
\hline 4 & Awake/alert \\
\hline
\end{tabular}

\section{Respiratory Depression}

A decrease in $\mathrm{SpO} 2$ of $<93 \%$ that required administration of supplemental oxygen via face mask or a RR of $<10$ breaths/min.

\section{Statistical Analysis}

- $\quad$ The result of continuous variables are given as mean +/SD and proportions as percentage.

- The difference between the three groups were assessed by ANOVA test (Analysis of Variance). For the comparison between 2 groups, unpaired ' $\mathrm{t}$ ' test was used. For categorical data, the difference between the groups was compared by using chi-square test. For all the tests, a ' $p$ ' value of 0.05 and less is considered to be statistically significant.

\section{RESULTS}

In the present study, the main parameters studied were haemodynamic changes, post-operative pain scores, duration of post-operative analgesia and incidence of side effects. All the three groups were comparable with respect to age and weight distribution. Haemodynamic changes were assessed through heart rate, systolic blood pressure and diastolic blood pressure. Post-operative pain was assessed using FLACC tool. Observations and results are as follows.

\begin{tabular}{|c|c|c|c|c|c|c|c|c|}
\hline \multicolumn{8}{|c|}{ Mean Weight of the Patients } \\
\hline \multirow{4}{*}{$\begin{array}{l}\text { Weight } \\
\text { in Kgs }\end{array}$} & Group R & Group RF & \multicolumn{1}{|c|}{ Group RN } & \multirow{2}{*}{$\begin{array}{c}\text { P- } \\
\text { Signifi- } \\
\end{array}$} & $\mathbf{n = 2 0}$ & \multicolumn{2}{|c|}{$\mathbf{n = 2 0}$} & \multicolumn{2}{|c|}{$\mathbf{n = 2 0}$} & value & cance \\
\cline { 2 - 7 } & Mean & SD & Mean & SD & Mean & SD & & \\
\cline { 2 - 6 } & 14.4 & 2.11 & 13.85 & 2.39 & 14.6 & 1.73 & 0.557 & NS \\
\hline \multicolumn{7}{|c|}{ Table 1. Mean Weight of the Patients } \\
\hline
\end{tabular}

Weight of children in Group R range from 10 - $18 \mathrm{kgs}$ with a mean weight of $14.4 \pm 2.11 \mathrm{kgs}$.

Weight of children in Group RF range from 10 - 19 kgs with a mean weight of $13.85 \pm 2.39$ kgs.

Weight of children in Group RN range from 11 - $18 \mathrm{kgs}$ with a mean weight of $14.6 \pm 1.73 \mathrm{kgs}$. 


\begin{tabular}{|c|c|c|c|}
\hline Group & $\begin{array}{c}\text { No. of } \\
\text { Patients }\end{array}$ & $\begin{array}{c}\text { Mean Age +/- } \\
\text { in Years }\end{array}$ & P value \\
\hline Group R & 20 & $5.65 \pm 1.19$ & \\
\hline Group RF & 20 & $5.35 \pm 1.46$ & \multirow{2}{*}{0.6852} \\
\hline Group RN & 20 & $5.3 \pm 1.3$ & \\
\hline \multicolumn{3}{|c}{ Table 2. Mean Age of Patients } \\
\hline
\end{tabular}

The mean age in Group $\mathrm{R}$ was $5.65 \pm 1.19$ years, in Group $\mathrm{RF}$ was $5.35 \pm 1.46$ years, in Group RN was $5.3 \pm 1.45$ years. A ' $\mathrm{p}$ ' value $>0.05$ was obtained suggesting no statistically significant difference between the three groups.

\begin{tabular}{|c|c|c|c|}
\hline \multirow{2}{*}{$\begin{array}{c}\text { Types of } \\
\text { Surgery }\end{array}$} & Group R & Group RF & Group RN \\
\cline { 2 - 4 } & n (\%) & n (\%) & n (\%) \\
\hline Herniotomy & $8(40 \%)$ & $7(35 \%)$ & $9(45 \%)$ \\
\hline Orchidopexy & $6(30 \%)$ & $5(25 \%)$ & $3(15 \%)$ \\
\hline Circumcision & $6(30 \%)$ & $8(40 \%)$ & $8(40 \%)$ \\
\hline
\end{tabular}

\section{Table 3. Different Surgical Procedures}

Different surgical procedures done during the study are as shown in Figure and Table.

Herniotomy accounted for $40 \%$ cases in Group R, 35\% in Group RF and 45\% in Group RN.

Orchidopexy accounted for 30\% cases in Group R, 25\% cases in Group RF and 15\% cases in Group RN.

Circumcision accounted for 30\% cases in Group R, 40\% cases in Group RF, 40\% cases in Group RN.

\begin{tabular}{|c|c|c|c|c|c|c|c|c|}
\hline \multicolumn{9}{|c|}{ Heart Rate } \\
\hline \multirow{3}{*}{$\begin{array}{l}\text { Time } \\
\text { in } \\
\text { Min }\end{array}$} & \multirow{2}{*}{\multicolumn{2}{|c|}{$\begin{array}{c}\text { Group R } \\
\mathrm{n}=20\end{array}$}} & \multirow{2}{*}{\multicolumn{2}{|c|}{$\begin{array}{c}\text { Group RF } \\
\mathbf{n}=20\end{array}$}} & \multirow{2}{*}{\multicolumn{2}{|c|}{$\begin{array}{c}\text { Group RN } \\
\mathbf{n}=\mathbf{2 0}\end{array}$}} & \multirow{3}{*}{$\begin{array}{c}\text { P- } \\
\text { value }\end{array}$} & \multirow{3}{*}{$\begin{array}{r}\text { Signifi- } \\
\text { cance }\end{array}$} \\
\hline & & & & & & & & \\
\hline & Mean & SD & Mean & SD & Mean & SD & & \\
\hline $\begin{array}{l}\text { Base } \\
\text { line }\end{array}$ & 96 & 9.40 & 98.2 & 6.47 & 97.95 & 5.1 & 0.58 & NS \\
\hline 0 & 100.85 & 9.43 & 99.85 & 5.56 & 99.1 & 4.29 & 0.72 & NS \\
\hline 5 & 103.75 & 8.67 & 101.8 & 5.27 & 102.45 & 4.54 & 0.62 & NS \\
\hline 15 & 104.95 & 8.65 & 105.05 & 5.37 & 106.4 & 4.8 & 0.73 & NS \\
\hline 30 & 94.05 & 6.52 & 96.65 & 6.18 & 96.55 & 3.99 & 0.268 & NS \\
\hline 45 & 93 & 6.3 & 95.95 & 5.65 & 92.85 & 4.27 & 0.139 & NS \\
\hline 60 & 91.3 & 4.85 & 94.05 & 5.46 & 91.4 & 4 & 0.131 & NS \\
\hline 120 & 92.1 & 6.21 & 94.1 & 5.99 & 92 & 4.9 & 0.43 & NS \\
\hline 180 & 90.25 & 5.76 & 93.65 & 7.34 & 90.2 & 5.64 & 0.148 & NS \\
\hline
\end{tabular}

In Group R, mean baseline heart rate was $96 \pm 7.8$ per minute, which rose to $104.95 \pm 8.65$ at 15 minutes. The heart rate gradually decreased to $90.25 \pm 5.76$ per minute at 180 minutes.

In Group RF the mean baseline heart rate was $98.2 \pm 6.47$ per minute, which increased to $105.05 \pm 5.37$ per minute at 15 minutes and gradually decreased to $93.65 \pm 7.34$ per minute at 180 minutes.

In Group RN the mean baseline heart rate was $97.95 \pm$ 5.10 per minute, which increased to $106.4 \pm 4.8$ per minute at 15 minutes. It gradually declined to $90.2 \pm 5.64$ per minute at 180 minutes.

However, there was no statistical difference between the three groups in heart rate at any time interval with a $p$-value of $>0.05$.

\begin{tabular}{|c|c|c|c|c|c|c|c|c|}
\hline \multicolumn{9}{|c|}{ Systolic Blood Pressure } \\
\hline \multirow{3}{*}{$\begin{array}{l}\text { Time } \\
\text { in } \\
\text { Min }\end{array}$} & \multirow{2}{*}{\multicolumn{2}{|c|}{$\begin{array}{c}\text { Group R } \\
\mathbf{n}=20\end{array}$}} & \multirow{2}{*}{\multicolumn{2}{|c|}{$\begin{array}{c}\text { Group RF } \\
n=20\end{array}$}} & \multirow{2}{*}{\multicolumn{2}{|c|}{$\begin{array}{c}\text { Group RN } \\
\mathrm{n}=20\end{array}$}} & \multirow{3}{*}{$\begin{array}{c}P- \\
\text { value }\end{array}$} & \multirow{3}{*}{$\begin{array}{l}\text { Signif } \\
\text {-cance }\end{array}$} \\
\hline & & & & & & & & \\
\hline & Mean & SD & Mean & SD & Mean & SD & & \\
\hline $\begin{array}{l}\text { Base } \\
\text { line }\end{array}$ & 104 & 6.36 & 101.7 & 5.96 & 102.7 & 6.6 & 0.52 & NS \\
\hline 0 & 106.5 & 7.37 & 103.3 & 6.03 & 104.1 & 6.4 & 0.302 & NS \\
\hline 5 & 110 & 7.48 & 106.7 & 5.55 & 110.2 & 5.8 & 0.155 & NS \\
\hline 15 & 106 & 6.55 & 106.2 & 6.35 & 106.9 & 4.33 & 0.877 & NS \\
\hline 30 & 104.3 & 5.12 & 104.8 & 6.5 & 103.6 & 3.79 & 0.769 & NS \\
\hline 45 & 103.8 & 5.94 & 102.6 & 5.92 & 102.4 & 3.25 & 0.655 & NS \\
\hline 60 & 100.5 & 5.54 & 99.7 & 5.08 & 98.3 & 2.99 & 0.328 & NS \\
\hline 120 & 96.5 & 2.96 & 98.5 & 4.49 & 97.7 & 2.99 & 0.234 & NS \\
\hline 180 & 97.2 & 2.93 & 97.8 & 4.25 & 96.7 & 3.45 & 0.626 & NS \\
\hline & able. & Chan & es in & & tolic & lood & & \\
\hline
\end{tabular}

In Group $\mathrm{R}$, mean baseline systolic blood pressure was $104 \pm 6.36 \mathrm{mmHg}$. It increased to $110 \pm 7.48 \mathrm{mmHg}$ at 5 minutes and then decreased to $97.2 \pm 2.93 \mathrm{mmHg}$ at 180 minutes.

In Group RF, mean baseline systolic blood pressure was $101.7 \pm 5.96 \mathrm{mmHg}$. It increased to $106.7 \pm 5.55 \mathrm{mmHg}$ at 5 minutes and then decreased to $97.8 \pm 4.25 \mathrm{mmHg}$ at 180 minutes.

In Group RN, mean baseline systolic blood pressure was $102.7 \pm 6.6 \mathrm{mmHg}$. It increased to $110.2 \pm 5.8 \mathrm{mmHg}$ at 5 minutes and then decreased to $96.7 \pm 3.45 \mathrm{mmHg}$ at 180 minutes.

At all time intervals, the P value was $>0.05$ and hence the difference in the mean systolic pressures between the three groups was not statistically significant.

\begin{tabular}{|c|c|c|c|c|c|c|c|c|}
\hline \multicolumn{9}{|c|}{ Diastolic Blood Pressure } \\
\hline \multirow{3}{*}{$\begin{array}{l}\text { Time } \\
\text { in } \\
\text { Min }\end{array}$} & Gro & up $R$ & Grou & p RF & Grol & p RN & \multirow{3}{*}{$\begin{array}{c}P- \\
\text { value }\end{array}$} & \multirow{3}{*}{$\begin{array}{c}\text { Signifi- } \\
\text { cance }\end{array}$} \\
\hline & \multicolumn{2}{|c|}{$\mathrm{n}=20$} & \multicolumn{2}{|c|}{$\mathrm{n}=20$} & \multicolumn{2}{|c|}{$\mathrm{n}=20$} & & \\
\hline & Mean & SD & Mean & SD & Mean & SD & & \\
\hline $\begin{array}{l}\text { Base } \\
\text { line }\end{array}$ & 66 & 6.12 & 64 & 7.2 & 64 & 6.42 & 0.55 & NS \\
\hline 0 & 67.3 & 6.3 & 65.5 & 7.26 & 63.5 & 6.42 & 0.206 & NS \\
\hline 5 & 70.3 & 5.96 & 71.1 & 6.91 & 67.8 & 6.42 & 0.248 & NS \\
\hline 15 & 71.1 & 5.09 & 72.3 & 6.53 & 68.6 & 6.13 & 0.142 & NS \\
\hline 30 & 66.7 & 5.08 & 69.2 & 6.14 & 66.7 & 4.32 & 0.322 & NS \\
\hline 45 & 66.3 & 4.87 & 64.7 & 6.47 & 63.4 & 4.45 & 0.235 & NS \\
\hline 60 & 63.7 & 4.6 & 62 & 7.5 & 60.2 & 4.37 & 0.158 & NS \\
\hline 120 & 64.6 & 4.1 & 63.2 & 7.21 & 60.5 & 4.72 & 0.065 & NS \\
\hline 180 & 64.7 & 4.37 & 64.7 & 7.3 & 61.2 & 4.42 & 0.129 & NS \\
\hline
\end{tabular}

Table 6. Changes in Diastolic Blood Pressure

The mean baseline diastolic blood pressure in Group $\mathrm{R}$ was $66 \pm 6.12 \mathrm{mmHg}$, which increased to a maximum of 71.1 $\pm 5.09 \mathrm{mmHg}$ at 15 minutes and then decreased to $64.7 \pm 4.37$ mmHg at 180 minutes.

The mean baseline diastolic blood pressure in Group RF was $64 \pm 7.2 \mathrm{mmHg}$, which increased to a maximum of $72.3 \pm$ $5.09 \mathrm{mmHg}$ at 15 minutes and then decreased to $64.7 \pm 7.3$ mmHg at 180 minutes.

The mean baseline diastolic blood pressure in Group $\mathrm{R}$ was $64 \pm 6.42 \mathrm{mmHg}$, which increased to a maximum of 68.6 $\pm 6.13 \mathrm{mmHg}$ at 15 minutes and then decreased to $61.2 \pm 4.42$ mmHg at 180 minutes. 
However, there was no statistically significant difference at any of the time intervals between the three groups, (P > $0.05)$.

\begin{tabular}{|c|c|c|c|c|c|c|c|c|}
\hline \multicolumn{9}{|c|}{ Pain Score } \\
\hline \multirow{3}{*}{$\begin{array}{l}\text { Time } \\
\text { in } \\
\text { Hrs. }\end{array}$} & \multirow{2}{*}{\multicolumn{2}{|c|}{$\begin{array}{c}\text { Group R } \\
\mathbf{n}=20\end{array}$}} & \multirow{2}{*}{\multicolumn{2}{|c|}{$\begin{array}{c}\text { Group RF } \\
\mathbf{n}=20\end{array}$}} & \multirow{2}{*}{\multicolumn{2}{|c|}{\begin{tabular}{|c|} 
Group RN \\
$\mathbf{n}=\mathbf{2 0}$ \\
\end{tabular}}} & \multirow{3}{*}{$\begin{array}{c}\text { P- } \\
\text { value }\end{array}$} & \multirow{3}{*}{$\begin{array}{r}\text { Signifi } \\
\text { cance }\end{array}$} \\
\hline & & & & & & & & \\
\hline & Mean & SD & Mean & SD & Mean & SD & & \\
\hline 1 & 0 & 0 & 0 & 0 & 0 & 0 & - & - \\
\hline 2 & 0 & 0 & 0 & 0 & 0 & 0 & - & - \\
\hline 3 & 0 & 0 & 0 & 0 & 0 & 0 & - & - \\
\hline 4 & 1.65 & 1.23 & 0.8 & 1 & 0 & 0 & $<0.05$ & $\mathrm{~S}$ \\
\hline 8 & 3.15 & 0.49 & 3.3 & 0.66 & 0.5 & 0.89 & $<0.05$ & $\mathrm{~S}$ \\
\hline 12 & 2.8 & 0.41 & 2.95 & 0.6 & 3.2 & 0.7 & 0.09 & NS \\
\hline 24 & 3.05 & 0.6 & 2 & 0.5 & 2.65 & 0.67 & 0.008 & $\mathrm{~S}$ \\
\hline \multicolumn{9}{|c|}{ Table 7. Pain Scores } \\
\hline
\end{tabular}

At the end of first 3 hours of post-operative period, all the three groups did not require any analgesics and mean pain score was 0 .

At the end of 4 hours, Group R and Group RF had a mean pain scores of $1.65 \pm 1.23$ and $0.8 \pm 1$ respectively, while it was 0 in Group RN with a $\mathrm{P}$ value of $<0.05$, which was statistically significant.

At the end of 8 hours, Group R and Group RF had a mean pain scores of $3.15 \pm 0.49$ and $3.3 \pm 0.66$ respectively, while it was $0.5 \pm 0.89$ in Group RN with a P value of $<0.05$ which was statistically significant.

At the end of 12 hours Group R, Group RF and Group RN had a mean pain score of $2.8 \pm 0.41,2.95 \pm 0.6$ and $3.2 \pm 0.7$ respectively with a $\mathrm{P}$ value of 0.09 , which was not statistically significant.

At the end of 24 hours Group R, Group RF and Group RN had a mean pain score of $3.05 \pm 0.6,2 \pm 0.5$ and $2.65 \pm 0.67$ respectively with a $\mathrm{P}$ value of 0.008 , which was statistically significant.

\begin{tabular}{|c|c|c|c|c|c|c|c|c|}
\hline \multicolumn{9}{|c|}{ Sedation Score } \\
\hline \multirow{3}{*}{$\begin{array}{c}\text { Time } \\
\text { in } \\
\text { Hrs. }\end{array}$} & \multirow{2}{*}{\multicolumn{2}{|c|}{$\begin{array}{c}\text { Group R } \\
\mathbf{n}=\mathbf{2 0}\end{array}$}} & \multirow{2}{*}{\multicolumn{2}{|c|}{$\begin{array}{c}\text { Group RF } \\
\mathbf{n = 2 0}\end{array}$}} & \multirow{2}{*}{\multicolumn{2}{|c|}{\begin{tabular}{|c|} 
Group RN \\
$\mathbf{n}=20$ \\
\end{tabular}}} & \multirow{3}{*}{$\begin{array}{c}\text { P- } \\
\text { value }\end{array}$} & \multirow{3}{*}{$\begin{array}{c}\text { Signifi- } \\
\text { cance }\end{array}$} \\
\hline & & & & & & & & \\
\hline & Mean & SD & Mean & SD & Mean & SD & & \\
\hline 1 & 2 & 0 & 2 & 0 & 2 & 0 & - & - \\
\hline 2 & 2 & 0 & 2 & 0 & 2 & 0 & - & - \\
\hline 3 & 2 & 0 & 2 & 0 & 2 & 0 & - & - \\
\hline 4 & 3.85 & 0.255 & 3.8 & 0.32 & 3.85 & 0.255 & & NS \\
\hline 8 & 3.95 & 0.22 & 3.9 & 0.31 & 3.8 & 0.32 & & NS \\
\hline 12 & 3.8 & 0.41 & 3.8 & 0.41 & 3.85 & 0.37 & 0.89 & NS \\
\hline 24 & 4 & 0 & 4 & 0 & 4 & 0 & & \\
\hline & & & able 8. & edat & $n S c c$ & & & \\
\hline
\end{tabular}

Mean sedation score was 2 (Asleep, but responding to verbal contact) in all the three groups upto 3 hours of postoperative period. By the end of the $4^{\text {th }}$ hour, most of the children were awake. Mean sedation scores were $3.85 \pm$ $0.255,3.8 \pm 0.32$ and $3.85 \pm 0.255$ in Group R, RF and RN respectively and this was not statistically significant. Most children in Group RN were calm.

The mean sedation scores at the end of $8 \mathrm{hrs}$. were $3.95 \pm$ $0.22,3.9 \pm 0.31$ and $3.8 \pm 0.32$ in Groups R, RF and RN respectively with no statistically significant difference.
Similar scores were observed at the end of 12 and 24 hours.

\begin{tabular}{|c|c|c|c|c|c|c|c|}
\hline \multicolumn{8}{|c|}{ Duration of Analgesia } \\
\hline \multirow{2}{*}{\multicolumn{2}{|c|}{$\begin{array}{c}\text { Group R } \\
n=20\end{array}$}} & \multirow{2}{*}{\multicolumn{2}{|c|}{$\begin{array}{c}\text { Group RF } \\
\mathbf{n}=20\end{array}$}} & \multirow{2}{*}{\multicolumn{2}{|c|}{$\begin{array}{c}\text { Group RN } \\
\mathbf{n}=\mathbf{2 0}\end{array}$}} & \multirow{3}{*}{$\begin{array}{c}\text { P- } \\
\text { value }\end{array}$} & \multirow{3}{*}{$\begin{array}{c}\text { Signifi- } \\
\text { cance }\end{array}$} \\
\hline & & & & & & & \\
\hline Mean & SD & Mean & SD & Mean & SD & & \\
\hline 333 & 40.14 & 353 & 31.14 & 680.5 & 62.53 & $<0.05$ & $\mathrm{~S}$ \\
\hline \multicolumn{8}{|c|}{ Table 9. Duration of Analgesia } \\
\hline
\end{tabular}

\begin{tabular}{|c|c|c|c|}
\hline \multicolumn{4}{|c|}{ Duration of Analgesia } \\
\hline \multicolumn{2}{|c|}{ Groups } & P value & Significance \\
\hline $\begin{array}{l}\text { Group R } \\
\text { (333 min) }\end{array}$ & $\begin{array}{l}\text { Group RF } \\
\text { (353 min) }\end{array}$ & 0.0863 & NS \\
\hline $\begin{array}{l}\text { Group R } \\
\text { (333 min) }\end{array}$ & $\begin{array}{c}\text { Group RN } \\
\text { (680.5 min) }\end{array}$ & $<0.001$ & S \\
\hline $\begin{array}{l}\text { Group RF } \\
\text { (353 min) }\end{array}$ & $\begin{array}{l}\text { Group RN } \\
(680.5 \mathrm{~min})\end{array}$ & $<0.001$ & S \\
\hline
\end{tabular}

Mean duration of analgesia was $333 \pm 40.14$ minutes in Group R, $353 \pm 31.14$ minutes in Group RF, while it was 680.5 \pm 62.53 minutes in Group RN. The difference in duration of analgesia between Ropivacaine group and RopivacaineNeostigmine group was significant with a P-value of $<0.01$, while that between Ropivacaine and Ropivacaine-Fentanyl group was not significant (P value- 0.0833 ).

\begin{tabular}{|c|c|c|c|}
\hline Complications & Group R & Group RF & Group RN \\
\hline Bradycardia & 0 & 0 & 0 \\
\hline Hypotension & 0 & 0 & 0 \\
\hline $\begin{array}{c}\text { Nausea and } \\
\text { vomiting }\end{array}$ & $2(10 \%)$ & $3(15 \%)$ & $5(25 \%)$ \\
\hline $\begin{array}{c}\text { Respiratory } \\
\text { depression }\end{array}$ & 0 & 0 & 0 \\
\hline \multicolumn{4}{|c|}{ Table 10. Complications } \\
\hline
\end{tabular}

\begin{tabular}{|c|c|c|c|}
\hline \multicolumn{4}{|c|}{ Nausea and Vomiting } \\
\hline \multicolumn{2}{|c|}{ Groups } & P-value & Significance \\
\hline Group R (10\%) & Group RF (15\%) & 0.28 & NS \\
\hline Group R (10\%) & Group RN (25\%) & 0.005 & S \\
\hline Group RF (15\%) & Group RN (25\%) & 3.12 & NS \\
\hline
\end{tabular}

Nausea and vomiting was observed in 2 out of $20(10 \%)$ patients in Group R, in 3 out of $20(15 \%)$ patients in Group RF and in 5 out of $20(25 \%)$ patients in Group RN.

There was a significant increase in the incidence of nausea and vomiting in the group receiving Neostigmine.

\section{DISCUSSION}

Caudal epidural analgesia is one of the most popular and commonly performed regional blocks in paediatric anaesthesia. It is a reliable and safe technique that can be used with general anaesthesia for intra-operative and postoperative analgesia in patients undergoing abdominal and lower limb surgery. The main disadvantage of caudal anaesthesia is the short duration of action after a single injection of local anaesthetic solution. Prolongation of caudal analgesia using a 'single-shot' technique has been achieved by the addition of various adjuvants.

In our study 60 children belonging to ASA 1 and 2, in the age group of 3 - 8 years undergoing elective infraumbilical surgeries were included. They were divided into 3 groups of 20 each. Group $\mathrm{R}$ received plain Ropivacaine, in Group RF Fentanyl $1 \mathrm{mcg} / \mathrm{kg}$ was added to Ropivacaine and Group RN 
received Ropivacaine + Neostigmine $2 \mathrm{mcg} / \mathrm{kg}$. The intraoperative haemodynamic changes, post-operative pain scores, duration of analgesia and incidence of side effects were noted.

Ropivacaine is a long-acting aminoamide local anaesthetic and was the first to be formulated as a pure S-enantiomer. Knudsen $\mathrm{K}$ et al[30] reported ropivacaine to have a better safety profile than bupivacaine with less risk for CNS and cardiac toxicity. Ropivacaine also causes less motor block than bupivacaine, a characteristic that may benefit children presenting for daycare surgery. Loennqvist PA et al[31] studied pharmacokinetics of Ropivacaine after caudal block in $1 \pm 8$ year old children and demonstrated the safety of caudal ropivacaine $0.2 \%(1 \mathrm{~mL} / \mathrm{kg})$ in children.

On the basis of current evidence, ropivacaine $0.2 \%$ appears to be the optimal concentration for paediatric caudal block. So we have chosen this concentration of ropivacaine for the present study.

Fentanyl is commonly added to local anaesthetics. However, the analgesic efficacy of caudal mixtures containing Fentanyl in children is less clear.

Ranjita A et al ${ }^{[32]}$ concluded that caudal fentanyl at dose of $1 \mu \mathrm{g} / \mathrm{kg}$ - 1 produces longer post-operative analgesia as compared to the dose of $0.5 \mu \mathrm{g} / \mathrm{kg}-1$ without any adverse effects.

Studies by Desai et al[33] and by Constant et al[34] concluded that caudal Fentanyl in a dose of $1 \mu \mathrm{g} / \mathrm{kg}$ provided satisfactory analgesia of longer duration with negligible respiratory depression.

So a safe dose of $1 \mathrm{mcg} / \mathrm{kg}$ of caudal fentanyl was used in the present study.

Neuraxial neostigmine is known to produce analgesia in animals, human volunteers and patients with pain as studied by Batra YK et al,[35] Eisenach JC et al[36] and Yaksh TL et al.[37] Neuraxial administration of this cholinesterase inhibitor inhibits breakdown of the endogenous spinal neurotransmitter acetylcholine, which has been shown to produce analgesia. The analgesic effect is thought to be mediated via spinal muscarinic $\left(\mathrm{M}_{1}\right)$ receptors as reported by Yaksh TL et al[37] and Bouaziz $\mathrm{H}$ et al.[38] Studies by Yang LC et al[ ${ }^{[3]}$ support the hypothesis of a peripheral anti-nociceptive effect of neostigmine. Studies by Turan et al ${ }^{[40]}$ and Dr. Rudra A et al ${ }^{[41]}$ have shown that neostigmine $2 \mathrm{mcg} / \mathrm{kg}-1$ prolonged the period of analgesia without increasing the incidence of adverse effects in children.

Keeping in view the above studies, neostigmine in a dose of $2 \mathrm{mcg} / \mathrm{kg}$ was used in the present study.

In the present study, there was no significant differences between the three groups regarding age and weight. The mean age in Group R was $5.65 \pm 1.19$ years, in Group RF it was $5.35 \pm 1.46$ years and in Group RN it was $5.3 \pm 1.45$ years. All the children in the three groups were in the age group of 3-8 yrs. In the study done by Y. Kawaraguchi et al,[42] comparing caudal block using Ropivacaine $0.2 \%$ with or without Fentanyl $1 \mathrm{mcg} / \mathrm{kg}^{1}$ children in the age group of $3-7$ years were studied. In the study by $\mathrm{A}$ Turan et al[40] comparing caudal block using Ropivacaine $0.2 \%$ with or without Neostigmine $2 \mathrm{mcg} / \mathrm{kg}^{1}$ children in the age group of 1-6 years were studied.

The mean weight in Group $\mathrm{R}$ was $14.4 \pm 2.11 \mathrm{kgs}$, in Group RF it was $13.85 \pm 2.39 \mathrm{kgs}$ and in Group RN it was 14.6 \pm 1.73 kgs. The mean weight of children in the study conducted by Y. Kawaraguchi et al[42] was 15.4 and $16.5 \mathrm{kgs}$ and in the study by A Turan et al[40] it was 18.5 and $18.2 \mathrm{kgs}$. This difference between the mean weights might be because of the smaller built of Indian children.

All the 60 children included in the study were boys, as the surgeries done were orchidopexy, circumcision and herniotomies.

In the present study, heart rate and blood pressure of all the patients were monitored at regular intervals. The mean baseline heart rate was similar in all the three groups. There was an initial increase in mean heart rate in all the three groups. This might be attributed to the various anaesthetic procedures done. After a time, gap of 10 - 15 mins, there was a decrease in the values in all the three groups.

Similarly, there was no significant difference in blood pressure (both systolic and diastolic) between the three groups at any time interval. After an initial rise in mean systolic pressure in all the three groups at 5 minutes, there was a gradual fall in the values falling slightly below the baseline values.

The mean diastolic blood pressure in all the three groups initially increased, followed by a gradual fall in values.

There was no incidence of hypotension or bradycardia in all the three groups.

The following studies have found similar changes in haemodynamic parameters as observed in the present study.

Jamali $\mathrm{S}$ et al and J Lee et al reported the lowest systolic pressures 1 - 2 hours after caudal injection. Haemodynamic changes appear to be less pronounced in children than in adults.

Usha Shukla et al[43] in their study on caudal fentanyl 1 $\mathrm{mcg} / \mathrm{kg}$ found that mean arterial pressures decreased by $10-$ $15 \%$ during anaesthesia and increased by $5-15 \%$ during recovery. HR also decreased during anaesthesia. In their study, no patient had a drop-in heart rate to less than 80 beats per minute.

Dr. Priyamvada Gupta et al[44] in a study on caudal Fentanyl with Ropivacaine observed that when compared to baseline values, heart rate and mean arterial pressures decreased intraoperatively followed by a post-operative increase. But still the post-operative values were lower than the baseline values. They did not observe any episodes of hypotension or bradycardia.

Abdul Atif $\mathrm{M}$ et al observed that intraoperatively, children receiving caudal bupivacaine or a bupivacaine/neostigmine mixture maintained haemodynamic stability. Dr. Rudra A et al[ $^{[41]}$ observed that children receiving caudal bupivacaine or a bupivacaine/neostigmine mixture maintained haemodynamic stability perioperatively and none of the patients showed severe bradycardia or hypotension.

Even with the rapid development of paediatric postoperative pain management, paediatric patients have remained under-treated for post-operative pain because of difficulty in pain assessment. Although numerous pain assessment tools are available, many scoring tools are complicated and not well validated and are difficult to use in clinical practice. When choosing a pain assessment tool, it is necessary to take into consideration the child's age, stage of development and clinical condition as stated by Rose JB et al.[45]

Many composite tools include both physiological and behavioural measures for determining pain scores, such as 
the Face, Leg, Activity, Cry, Consolability (FLACC) tool, COMFORT scale and Children Hospital of Eastern Ontario Pain scale. No single composite scale is clearly superior to the others. In the present study, we have used the Face, Leg, Activity, Cry, Consolability (FLACC) tool, which is a behavioural scale for measuring the intensity of postprocedural pain in young children. FLACC is an easy and practical scale to use in evaluating and measuring pain, especially in preverbal children from 2 months to 7 years. Numerous studies have proven its validity and reliability. It does not require patient participation. If the pain score is more than or equal to 4 at 2 consecutive intervals of 10 minutes, supplementary analgesic with rectal paracetamol $(15 \mathrm{mg} / \mathrm{kg})$ was given.

There was no pain in any child in all the three groups in the first 3 hours of post-operative period. In Group R and RF till the end of 3 hours and in Group RN till the end 4 hours mean pain score was 0 . There was a significant difference in pain scores between Group R and RN at the end of $4^{\text {th }}$ hour. Groups $\mathrm{R}$ and RF achieved higher pain scores at the end of 8 hours with $20 \%$ of patients in Group $\mathrm{R}$ and $40 \%$ patients in Group RF having pain scores $\geq 4$. The difference in pain scores between Group R and RF were insignificant at 4, 8 and 12 hours. These results are similar to those of Shukla et al[43] and Rudra et al.[41]

Duration of analgesia was defined as the time of caudal injection of drug to the first time the FLACC score was $\geq 4$ for two consecutive intervals of 10 minutes (First requirement of supplemental analgesia for patient). In the present study, mean duration of adequate caudal analgesia was $333+/-40.14$ minutes in Group R, $353 \pm 31.14$ minutes in Group RF and $680.5 \pm 62.53$ minutes in Group RN.

Though there was a slight increase in the duration of analgesia in Group RF when compared to Group R, this difference was not statistically significant.

Y. Kawaraguchi et al[42] found no statistical differences between caudal Ropivacaine with or without Fentanyl in the CHEOPS and Steward (Sedation) score, and the time to first analgesic requirement. They concluded that the addition of fentanyl $1 \mathrm{mcg} / \mathrm{kg}$ to ropivacaine $0.2 \%$ for caudal analgesia provides no further analgesic advantages over ropivacaine $0.2 \%$ alone.

Desai et al[35] conducted a study with two different doses of caudal fentanyl added to local anaesthetic solution. They found in their study that the duration of analgesia was $5.04 \pm$ $0.35 \mathrm{hrs}$. in Group I ( $1 \mathrm{mcg} / \mathrm{kg}$ fentanyl) and $3.30 \pm 0.57 \mathrm{hrs}$. in Group II ( $0.5 \mathrm{mcg} / \mathrm{kg}$ fentanyl). These results are similar to the present study where the duration of analgesia in Group $\mathrm{RF}$ (Fentanyl $1 \mathrm{mcg} / \mathrm{kg}$ ) was 353 +/- $31.14 \mathrm{~min}$.

Bharathi Muntha et al[46] in their study done to assess the analgesic efficacy and safety of addition of caudal fentanyl concluded that there was no added advantage of adding fentanyl to caudal bupivacaine for post-operative pain relief in children. Similar findings were also reported by Gharsallah et al[47] and Campbell et al.[48]

Dr. Priyamvada Gupta et $\mathrm{al}^{46]}$ and Usha Shukla et al[45] found that addition of fentanyl to ropivacaine as caudal analgesic provides prolonged post-operative analgesia in children.

Thus, the benefit of using Fentanyl as an adjunct to prolong the duration of analgesia in caudal block is debatable with some studies showing prolonged duration, while other studies have revealed to have no added benefit.

In the present study, the duration of analgesia in Group RN was $680.5+/-62.53$ minutes and the prolongation in the duration of analgesia was statistically significant with a $\mathrm{P}$ value of $<0.05$.

A Turan et al[40] conducted a study to evaluate analgesia and side effects of caudal neostigmine co-administered with ropivacaine. The duration of analgesia was statistically prolonged in children receiving Ropivacaine + Neostigmine (19.2 \pm 5.5 hrs.) when compared to children receiving plain Ropivacaine ( $7.1 \pm 5.7 \mathrm{hrs}$.) $(\mathrm{P}<0.05)$.

Abdul Atif $\mathrm{M}$ et al conducted a randomised, doubleblinded study to evaluate the analgesic efficacy of caudal neostigmine, bupivacaine or a mixture of both drugs in 60 children. They concluded that caudal neostigmine $2 \mathrm{mcg} / \mathrm{kg}$ given alone provides post-operative analgesia comparable to caudal bupivacaine in children and the co-administration of the two drugs was associated with extended post-operative analgesia and reduced need for supplementary analgesics.

D. Kaushal et al[49] in their study comparing the efficacy of caudal bupivacaine with or without neostigmine for perioperative analgesia found that caudal bupivacaine/neostigmine mixture resulted in superior analgesia compared with bupivacaine alone. Recovery to first rescue analgesic times were $6.05 \pm 2.04 \mathrm{hrs}$. in the bupivacaine group, $11.5 \pm 3.42 \mathrm{hrs}$. in bupivacaine neostigmine $2 \mu \mathrm{g} / \mathrm{kg}$ group and $16.86 \pm 4.92 \mathrm{hrs}$. in bupivacaine neostigmine $5 \mu \mathrm{g} / \mathrm{kg}$ groups $(\mathrm{p}<0.05)$. They concluded that co-administration of caudal neostigmine with bupivacaine significantly extends the duration of postoperative analgesia with reduced need for supplementary analgesics.

Dr. Rudra A et al examined the analgesic efficacy of caudal administration of bupivacaine or a mixture of bupivacaineneostigmine in 40 children. Caudal administration of bupivacaine with the addition of neostigmine resulted in superior analgesia compared with the other group. Duration of analgesia was $7.6 \pm 5.4$ hours in patients belonging to bupivacaine group, while it was $19.0 \pm 4.2$ hours in patients who received caudal bupivacaine plus neostigmine. Thus, they concluded that a single caudal co-administration of the two drugs is associated with extended duration of postoperative analgesia.

In the first three hours of post-operative period, all the children were asleep but responded to verbal commands. At the end of 4 hours the number of awake patients increased to $85 \%$ in Group R, 80\% in Group $\mathrm{RF}$ and $85 \%$ in Group RN. Most of the children in Group RN were calm. It was difficult to distinguish between sedation and analgesia in the present study groups as a pain-free child is calm, comfortable or asleep. Our results correlate well with those of Campbell et al. ${ }^{[48]}$

In the present study, there were no episodes of hypotension, bradycardia or post-operative respiratory depression as evidenced by a fall in respiratory rate to < $10 /$ minute or a fall in oxygen saturation to $<90 \%$.

Study by Desai et al[33] comparing bupivacaine $0.25 \%$ with two different doses of fentanyl $(1 \mathrm{mcg} / \mathrm{kg}$ and 0.5 $\mathrm{mcg} / \mathrm{kg}$ ) with adrenaline found that there was no significant differences in haemodynamic and respiratory parameters in between two groups. Gharshallah A et al[49] also reported 
similar findings. Dr. Rudra A et al[41] and A Turan et al[40] in their study on caudal neostigmine found that oxygen saturation was always within the clinically acceptable range (>96\%).

In the present study vomiting was seen in 2 patients $(10 \%)$ in Group R, 3 patients (15\%) in Group RF and 5 patients (25\%) in Group RN. The incidence of nausea and vomiting in Group RN was significantly higher. The following studies have shown similar results.

Bindi B Palkhiwla et al[50] observed that vomiting occurred with an incidence of $8 \%$ in children receiving $0.2 \%$ Ropivacaine.

Y. Kawaraguchi et al[42] observed that the incidence of post-operative vomiting was not significantly different between groups receiving either plain $0.2 \%$ Ropivacaine or Ropivacaine Fentanyl $(1 \mathrm{mcg} / \mathrm{kg})$ mixture via the caudal route.

Batra YK et al[35] observed that Neostigmine dose exceeding $30 \mathrm{mcg} / \mathrm{kg}$ is associated with a higher incidence of nausea and vomiting. Dr. Rudra et al[41] and A Turan et al[42] did not find any statistically significant difference in the incidence of nausea and vomiting with the addition of caudal Neostigmine.

\section{SUMMARY AND CONCLUSION}

The present study was done to compare the efficacy and safety of addition of fentanyl and neostigmine to Ropivacaine as a single shot caudal block in sub-umbilical surgeries in children. Sixty paediatric patients belonging to ASA Grade I and II were selected for this study.

\section{They were divided into 3 groups of 20 each-}

- $\quad$ Group R received 0.2\% Ropivacaine.

- Group RF received 0.2\% Ropivacaine with Fentanyl 1 $\mathrm{mcg} / \mathrm{kg}$.

- Group RN received 0.2\% Ropivacaine with Neostigmine $2 \mathrm{mcg} / \mathrm{kg}$.

The main parameters studied were haemodynamic changes, duration of post-operative analgesia and incidence of side effects. All the three groups were comparable with respect to age and weight distribution. Post-operative pain was assessed using FLACC tool and rectal Paracetamol was given if the score reached 4 or more.

There was no statistically significant difference between the three groups with respect to haemodynamic parameters like heart rate, systolic blood pressures and diastolic blood pressures.

At the end of 4 hours, the difference in pain scores between the 3 groups was statistically significant with a $P$ value of $<0.05$. At the end of 8 hours also, $\mathrm{P}$ value was $<0.05$ which was statistically significant.

Mean duration of analgesia was $333+/-40.14$ minutes in Group R, $353 \pm 31.14$ minutes in Group RF, while it was 680.5 \pm 62.53 minutes in Group RN showing a statistically significant difference. Though there was a slight increase in the duration of analgesia in Group RF when compared to Group $\mathrm{R}$ this difference was not statistically significant, whereas the difference in duration of analgesia between Group RN and the other two groups was statistically significant.
The duration of sedation corresponded closely with the duration of analgesia. Nausea and vomiting was observed in 2 out of $20(10 \%)$ patients in Group R, in 3 out of $20(15 \%)$ patients in Group RF and in 5 out of 20 (25\%) patients in Group RN which was statistically significant.

Thus, to conclude, in the present study we found that the addition of neostigmine to caudal Ropivacaine caused a prolongation of duration of analgesia, while a ropivacaine and fentanyl mixture did not cause any statistically significant increase in the duration of analgesia. Caudal neostigmine was associated with an increase in the incidence of nausea and vomiting.

The limitation in the present study was that the type of surgical procedures were varied. The intensity of postoperative pain may vary depending on the type of surgical procedure.

\section{REFERENCES}

[1] Merskey H, Bogduk N. Part III: pain terms, a current list with definitions and notes on usage. $2^{\text {nd }}$ edn. Classification of chronic pain, IASP task force on taxonomy, IASP Press, Seattle 1994:209-14.

[2] Anand KJ, Carr DB. The neuroanatomy, neurophysiology, and neurochemistry of pain, stress, and analgesia in newborns and children. Pediatr Clin N Am 1989;36(4):795-822.

[3] Anand KJ, Hickey PR. Pain and its effects in the human neonate and fetus. N Engl J Med 1987;317(21):13219.

[4] Wolf A. Development of pain and stress responses. In: proceedings of the 4th European congress of paediatric anaesthesia, Paris 1997.

[5] Choonara I. Management of pain in newborn infants. Semin Perinatol 1992;16(1):32-40.

[6] Bosenberg A. Pediatric regional anesthesia update. Paediatr Anaesth 2004;14(5):398-402.

[7] Dalens B. Some open questions in pediatric regional anesthesia. Minerva Anestesiol 2003;69(5):451-6.

[8] De Negri P, Ivani G, Tirri T, et al. New drugs, new techniques, new indications in pediatric regional anesthesia. Minerva Anestesiol 2002;68(5):420-7.

[9] Ross AK, Eck JB, Tobias JD. Pediatric regional anesthesia: beyond the caudal. Anesth Analg 2000;91(1):16-26.

[10] Wolf AR, Doyle E, Thomas E. Modifying infant stress responses to major surgery: spinal vs extradural vs opioid analgesia. Paediatric Anaesthesia 1998;8(4):305-11.

[11] Wolf AR, Eyres RL, Laussen PC, et al. effect of extradural analgesia on stress responses to abdominal surgery in infants. Br J Anaesth 1993;70(6):654-60.

[12] Campbell MF. Caudal anesthesia in children. Am J Urol 1933;30:245-9.

[13] Wolf AR, Hughes D, Mather SJ, et al. Postoperative analgesia after paediatric orchidopexy: evaluation of a bupivacaine morphine mixture. British Journal of Anesthesia 1990;64:430-5.

[14] Schuepfer G, Konrad C, Schmeck J, et al. Generating a learning curve for pediatric caudal epidural blocks: an empirical evaluation of technical skills in novice and experienced anesthetists. Reg Anesth Pain Med 2000;25(4):385-8. 
[15] Krane EJ, Tyler DC, Jacobson LE. The dose response of caudal morphine in children. Anesthesiology 1989;71(1):48-52.

[16] Naguib M, Sharif AM, Seraj M, et al. Ketamine for caudal analgesia in children: comparison with caudal bupivacaine. Br J Anaesth 1991;67(5):559-64.

[17] Lee JJ, Rubin AP. Comparison of a bupivacaineclonidine mixture with plain bupivacaine for caudal analgesia in children. Br J Anaesth 1994;72(3):258-62.

[18] Jamali S, Monin S, Begon C, et al. Clonidine in pediatric caudal anesthesia. Anesth Analg 1994;78(4):663-6.

[19] Abdulatif M, El-Sanabary M. Caudal neostigmine, bupivacaine, and their combination for postoperative pain management after hypospadias surgery in children. Anesth Analg 2002;95(5):1215-8.

[20] Berde CB. Toxicity of local anesthetics in infants and children. J Pediatr 1993;122(5 Pt 2):S14-20.

[21] Wolf AR, Valley RD, Fear DW, et al. Bupivacaine for caudal analgesia in infants and children: the optimal effective concentration. Anesthesiology 1988;69(1):102-6.

[22] Ivani G, De Negri P, Lonnqvist PA, et al. Caudal anesthesia for minor pediatric surgery: a prospective randomized comparison of ropivacaine $0.2 \%$ vs levobupivacaine $\quad 0.2 \%$. Paediatr Anaesth 2005;15(6):491-4.

[23] Chalkiadis GA, Eyres RL, Cranswick N, et al. Pharmacokinetics of levobupivacaine $0.25 \%$ following caudal administration in children under 2 years of age. Br J Anaesth 2004;92(2):218-22.

[24] Ivani G, Tonetti F. Postoperative analgesia in infants and children: new developments. Minerva Anestesiol 2004;70(5):399-403.

[25] Bosenberg AT, Cronje L, Thomas J, et al. Ropivacaine plasma levels and postoperative analgesia in neonates and infants during 48-72 $\mathrm{h}$ continuous epidural infusion following major surgery. Paediatr Anaesth 2003;13:851-2.

[26] Ivani G. Ropivacaine: is it time for children? Paediatr Anaesth 2002;12(5):383-7.

[27] Ivani G, DeNegri P, Conio A, et al. Comparison of racemic bupivacaine, ropivacaine, and levobupivacaine for pediatric caudal anesthesia: effects on postoperative analgesia and motor block. Reg Anesth Pain Med 2002;27(2):157-61.

[28] De Negri P, Ivani G, Tirri T, et al. A comparison of epidural bupivacaine, levobupivacaine, and ropivacaine on postoperative analgesia and motor blockade. Anesth Analg 2004;99(1):45-8.

[29] Da Conceicao MJ, Coelho L, Khalil M. Ropivacaine $0.25 \%$ compared with bupivacaine $0.25 \%$ by the caudal route. Paediatr Anaesth 1999;9(3):229-33.

[30] Knudsen K, SuurkuÈla BM, Blomberg S, et al. Central nervous and cardiovascular effects of i.v. infusions of ropivacaine, bupivacaine and placebo in volunteers. $\mathrm{Br}$ J Anaesth 1997;78(5):507-14.

[31] LoÈnnqvist PA, Westrin P, Larsson BA, et al. Ropivacaine pharmacokinetics after caudal block in 18 year-old-children. Br J Anaesth 2000;85(4):506-11.

[32] Acharya R, Jena SK, Samal S, et al. Postoperative analgesia in paediatrics patients through caudal block with bupivacaine and two different doses of fentanyl a comparative study. Jemds 2013;2(39):7568-74.

[33] Desai DJ, Swadia VN, Gupta KK. Comparative study of two different doses of fentanyl with $0.25 \%$ bupivacaine through caudal route for paedriatic anaesthesia and post-operative analgesia. J Anaesth Clin Pharmacol 2008;24:31-4.

[34] Constant I, Gall O, Gouyet L, et al. Addition of clonidine or fentanyl to local anaesthetics prolongs the duration of surgical analgesia after single shot caudal block in children. Br J Anaesth 1998;80(3):294-8.

[35] Batra YK, Arya VK, Mahajan R, et al. Dose response study of caudal neostigmine for post-operative analgesia in paediatric patients undergoing genitourinary surgery. Paediatr Anaesth 2003;13(6):515-21.

[36] Eisenach JC, Hood DD, Curry R. Phase I human safety assessment of intrathecal neostigmine containing methyl and propylparabens. Anesth Analg 1997;85(4):842-6.

[37] Yaksh TL, Collins JG. Studies in animals should precede human use of spinally administered drugs. Anesthesiology 1989;70(1):4-6.

[38] Bouaziz H, Tong C, Eisenach JC. Postoperative analgesia from intrathecal neostigmine in sheep. Anesth Analg 1995;80(6):1140-4.

[39] Yang LC, Chen LM, Wang CJ, et al. Postoperative analgesia: intra-articular neostigmine in patients undergoing knee arthroscopy. Anesthesiology 1998;88(2):334-9.

[40] Turan A, Memis D, Basaran UN, et al. Caudal ropivacaine and neostigmine in pediatric surgery. Anesthesiology 2003;98(3):719-22.

[41] Rudra A, Pan AK, Acharya A, et al. Scope of caudal neostigmine with bupivacaine for post operative analgesia in children: comparison with bupivacaine. Indian J Anaesth 2005;49(3):191-4.

[42] Kawaraguchi Y, Otomo T, Ota C, et al. A prospective, double-blind, randomized trial of caudal block using ropivacaine $0.2 \%$ with or without fentanyl $1 \mu \mathrm{g} \mathrm{kg-1}$ in children. Br J Anaesth 2006;97(6):858-61.

[43] Shukla U, Prabhakar T, Malhotra K. Postoperative analgesia in children when using clonidine or fentanyl with ropivacaine given caudally. $\mathrm{Br} \mathrm{J}$ Anaesth 2011;27(2):205-10.

[44] Gupta P, Sharma P, Jethava D, et al. A comparison of ropivacaine alone and in combination with fentanyl for caudal analgesia in pediatric patients. IOSR-JDMS 2014;13(11):1-4.

[45] Rose JB, Logan DE. Pediatric pain assessment. In: Litman RS (edr). Pediatric anesthesia. The requisites in anesthesiology. Philadelphia: Elsevier Mosby 2004:191-5.

[46] Muntha B, Talikota N, Kumar P, et al. Post-operative pain management in children with caudal bupivacaine versus caudal bupivacaine with fentanyl. International Journal of Scientific Study 2015;2(12).

[47] Gharsallah A, Atallah T, Hmouda H, et al. Evaluation of 2 dosages of fentanyl in caudal anesthesia. A 
prospective randomized double-blind study. Cah Anesthesiol 1996;44(5):419-21.

[48] Campbell FA, Yentis SM, Fear DW, et al. Analgesic efficacy and safety of a caudal bupivacaine-fentanyl mixture in children. Can J Anaesth 1992;39(7):661-4.

[49] Kaushal D, Singh V, Abbas H, et al. Caudal bupivacaineneostigmine for perioperative analgesia in pediatric patients undergoing infraumbilical surgeries: a prospective, randomized, double blind, controlled study. The Internet Journal of Anesthesiology 2008;21(1).

[50] Palkhiwla BB, Gajjar HR, Shah RS. Study of caudal anaesthesia with ropivacaine under sedation for infraumbilical surgery in paediatrics patients. NHL Journal of Medical Sciences 2014;3(1):37-40. 